\title{
Penggunaan Daya Panel Surya Dengan MPPT Bisection Pada Proses Charging Baterai
}

\author{
Lucky Pradigta Setiya Raharja $^{1 *}$, Rachma Prilian Eviningsih ${ }^{2}$, Indra Ferdiansyah $^{3}$, \\ Diah Septi Yanaratri ${ }^{4}$ \\ ${ }^{1,2,3,4}$ Politeknik Elektronika Negeri Surabaya \\ *lucky@pens.ac.id
}

\begin{abstract}
Currently, the use of renewable energy is growing rapidly. Solar panels are a technology that is widely used to produce electrical energy from sunlight. The electrical energy from solar panels can be used directly or can be stored in batteries. The storage of electrical energy from solar panels is done by charging the battery with electrical power generated by the solar panel. To maximize the output power from solar panels, the MPPT Bisection method with Interleaved Boost Converter (IBC) is used to regulate the power output from the solar panels. The MPPT Bisection algorithm is built with C-Code in the PSIM simulation software. System simulation with MPPT Bisection shows good results. The power generated from solar panels can reach between $98.47 \%$ to $99.84 \%$ of the maximum power of the solar panels with Standard Light Intensities between $1000 \mathrm{~W} / \mathrm{m} 2$ to $400 \mathrm{~W} / \mathrm{m} 2$. The output voltage for battery charge has $0.19 \%$ ripple voltage so that it can be used for the battery charge process properly. By using the MPPT Bisection method and the Interleaved Boost Converter, it can maximize the output of solar panel power and has a very small voltage ripple.
\end{abstract}

Keywords: Solar Panel, Interleaved Boost Converter, MPPT Bisection, Battery

\begin{abstract}
Abstrak
Penggunanan energi terbaharukan semakin pesat pada jaman ini. Panel surya merupakan salah satu yang banyak digunakan untuk menghasilkan energi listrik dari sinar matahari. Energi listrik dari panel surya dapat digunakan secara langsung atau dapat disimpan pada baterai. Pada proses penyimpanan energi listrik dari panel surya dilakukan dengan cara melakukan charge pada baterai dengan daya listrik yang dihasilkan oleh panel surya. Untuk memaksimalkan daya keluaran dari panel surya digunakan metode MPPT Bisection dengan Interleaved Boost Converter (IBC) untuk mengatur daya yang dikeluarkan dari panel surya. Algoritma MPPT Bisection dibangun dengan C-Code pada simulasi software PSIM. Dari hasil sistem yang dibangun menggunkan MPPT Bisection dapat berjalan dengan baik. Daya yang dihasilkan dari panel surya bisa mencapai antara $98.47 \%$ sampai dengan $99.84 \%$ dari daya maksimum panel surya dengan Standard Light Intensity antara $1000 \mathrm{~W} / \mathrm{m}^{2}$ sampai dengan $400 \mathrm{~W} / \mathrm{m}^{2}$. Tegangan yang dikeluarkan untuk charge baterai memiliki riple tegangan yang sangat kecil yaitu $0.19 \%$ sehingga dapat digunakan untuk proses charge baterai dengan baik. Dengan menggunakan metode MPPT Bisection dan Interleaved Boost Converter dapat memaksimalkan hasil keluaran daya panel surya dan memiliki ripel tegangan yang sangat kecil.
\end{abstract}

Kata kunci: Panel Surya, Interleaved Boost Converter, MPPT Bisection, Baterai

\section{Pendahuluan}

Semakin

penduduk setiap

permintaan akan pasokan listrik juga bertambah. Hal ini membuat banyak negara termasuk Indonesia sudah mulai beralih dari sumber energi tak terbarukan menjadi energi terbarukan atau renewable energy sehingga 
krisis energi juga tidak akan terjadi. Energi matahari merupakan salah satu sumber energi terbarukan yang dapat diandalkan, bersih, ramah lingkungan, serta tidak pernah habis. [1]

Panel surya dapat mengubah energi cahaya matahari menjadi energi listrik. Daya keluaran dari panel surya sangat dipengaruhi oleh kondisi lingkungan yang berubah-ubah sehingga dapat menyebabkan fluktuasi daya disisi beban. Selain itu, kondisi suhu, iradiasi matahari, dan titik operasi karena hubungan arus-tegangan (I-V) nonlinear juga bisa menyebabkan fluktuasi daya. Dengan kondisi tersebut, tidaklah mudah menentukan metode maximum power point (MPP) untuk mendapatkan daya maksimum dengan kondisi lingkungan yang berubah-ubah sehingga daya keluaran dapat dimaksimalkan. [2], [3], [4].

Direct methods, artificial intelligence, dan indirect methods merupakan tiga kategori pada metode maximum power point tracking (MPPT). Direct methods terdiri dari perturb and observe, incremental conductance, dan hill climbing (HC). Kelemahannya jika menggunakan direct methods adalah proses pencarian MPP yang lambat sehingga kurang cocok jika digunakan dengan kondisi lingkungan yang berubah-ubah. Yang termasuk di dalam metode artificial intelligence adalah fuzzy logic dan nueral network. Namun jika menerapkan metode tersebut tidaklah mudah. Sedangkan yang termasuk dalam indirect methods adalah fractional open circuit voltage (OCV) and fractional short circuit current (SCC). Metode ini sangatlah sederhana namun akurasi metode ini tidaklah bagus. [4],[5],[6]

Pada penelitian ini mengusulkan sebuah metode MPPT yang didasarkan pada Bisection Search Theorem (BST) tanpa memerlukan komputasi turunan. Dengan demikian, teknik baru ini bahkan lebih sederhana dalam komputasi, lebih murah dalam implementasi dan lebih cepat dalam pelacakan. Pada penelitian ini juga digunakan interleaved boost converter untuk mengatur daya yang dikeluarkan dari panel surya. Dengan menggunakan metode MPPT Bisection dan
Interleaved Boost Converter dapat memaksimalkan hasil keluaran daya panel surya dan memiliki ripel tegangan yang sangat kecil sehingga dapat digunakan untuk proses charge baterai dengan baik.[7],[8],[9].

\section{Metoda Penelitian}

\subsection{Panel Surya}

Panel surya adalah komponen yang dapat menghasilkan daya listrik dalam satuan waktu dalam tegangan dan arus DC. Panel surya merubah energi sinar matahari yang ditangkap menjadi energi listrik tersebut. Tegangan dan arus yang dihasilkan dapat dikategorikan tidak linier karena dipengaruhi dari energi sinar matahari yang diperoleh dan beban yang disupplai oleh panel surya tersebut. Untuk menunjukkan tipikal dari panel surya [6] dapat ditunjukkan dengan rangkaian pengganti seperti pada rangkaian elektrik pada gambar 1.

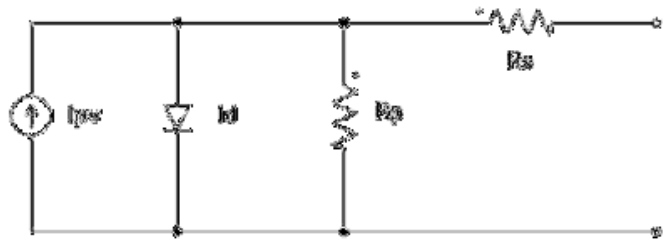

Gambar 1.

Rangkaian Elektrik Pengganti Model Panel Surya

Dari gambar 1 rangkaian pengganti model panel surya dapat diketahui untuk persamaan arus dengan $I_{p v}$ merupakan arus panel surya (sel) dan $I_{d}$ merupakan penunjukan untuk arus dioda (Shockley) sehingga besar arus dapat ditunjukkan dengan persamaan:

$I=I_{p v}-I_{d}$

$I_{d}=I_{o} *\left[\exp \left(\frac{q * V}{a * k * T}\right)-1\right]$

Dari persamaan $1 \& 2$ dilakukan substitusi sehingga didapatkan arus:

$$
I=I_{p v}-I_{o} *\left[\exp \left(\frac{q * V}{a * k * T}\right)-1\right]
$$

Terlihat adanya reistansi pararel dan seri pada rangkaian elektrik pengganti dari panel surya sehingga menjadi persaamaan (3) menjadi: 


$$
\begin{aligned}
& \text { JURNAL TEKNOLOGI TERPADU VOL. } 9 \text { NO. } 1 \\
& \begin{aligned}
I & I_{p v}-I_{O} *\left[\exp \left(\frac{q *\left(V+I * R_{S}\right)}{a * k * T}\right)-1\right] \\
& -\frac{V+I * R_{S}}{R p}
\end{aligned}
\end{aligned}
$$

Dimana $I_{o}$ menunjukkan arus saturasi diode, $\mathrm{q}$ merupakan electron chrage $\left(1.6 * 10^{-19} \mathrm{C}\right), \mathrm{k}$ merupakan konstanta Boltzman $\left(1.38 * 10^{-23}\right.$ $\mathrm{J} / \mathrm{K})$, a merupakan ideality factor dan $\mathrm{T}$ merupakan Temperature (K).

\subsection{Interleaved Boost}

Interleaved Boost Converter (IBC) [2],[7],[9] merupakan DC-DC konverter yang dapat menaikkan tegangan DC masukan dengan tegangan keluran yang memiliki ripple tegangan yang lebih kecil dibandingkan dengan keluaran tegangan Boost Converter serta ripple arus masukan yang lebih kecil. Interleaved Boost Converter merupakan pengembangan topologi dari Boost Converter. Pengembangan dilakukan dengan melakukan pararel dari induktor serta dilakukan proses switching dengan jumlah sesuai dengan pararel induktor yang digunakan. Untuk Interleaved Boost Converter yang menggunakan 2 induktor dan 2 switching yang ditunjukkan seperti pada rangkaian gambar 2 berikut:

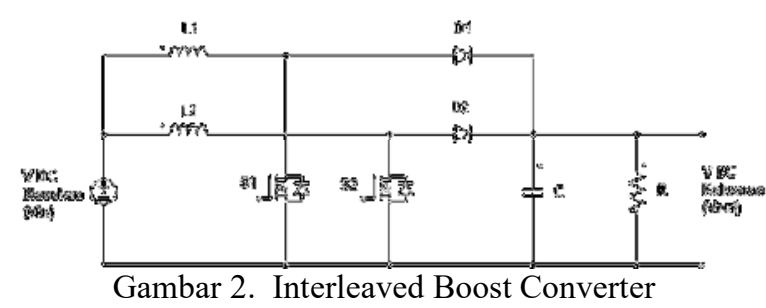

Pada penentuan besarnya nilai komponen Interleaved Boost Converter untuk induktor (L) dan kapasistor (C) serta besarnya tegangan DC keluaran berdasarkan nilai dutycycle (D) maka ditunjukkan pada persamaan :

$$
\Delta I_{L}=\% \text { ripple arus } * I_{L}
$$

$L=\frac{V_{i n} * D}{\Delta I_{L} * f_{S}}$
APRIL 2021

ISSN: $2338-66649$

Dimana L merupakan nilai induktor $(\mathrm{H}), V_{\text {in }}$ merupakan besar tegangan masukan (VDC), D merupakan dutycycle (\%), $\Delta I_{L}$ merupakan ripple arus dari induktor (A) dan $f_{s}$ merupakan frekuensi pensakalaran/Switcing $(\mathrm{Hz})$.

$\Delta V_{o}=\%$ ripple Tegangan $* V_{o}$

$C=\frac{I_{o} * D}{\Delta V_{o} * f_{S}}$

Dimana $\mathrm{C}$ merupakan nilai kapasitor $(\mathrm{F}), I_{o}$ merupakan arus keluaran (A), D merupakan dutycycle (\%), $\Delta V_{o}$ merupakan ripple tegangan keluaran (V) dan $f_{s}$ merupakan frekuensi pensakalaran /Switcing (Hz).

Pada Interleaved Boost Converter terdapat 4 kondisi kerja dari konverter ini berdasarkan kondisi dari switch 1 (S1) dan switch 2 (S2).

Kondisi 1: dimana $\mathrm{S} 1=$ TUTUP dan $\mathrm{S} 2=$ BUKA akan ditunjukan ilustrasi pada gambar 3.

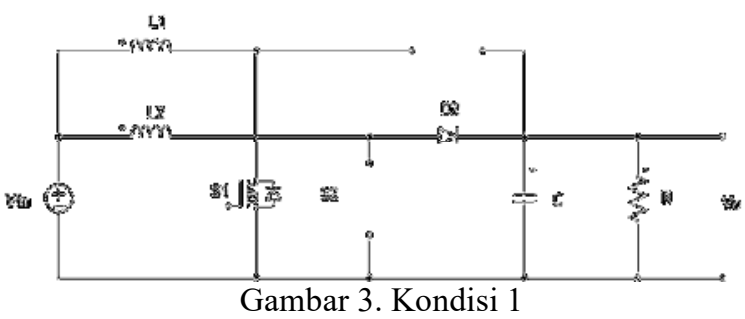

Pada kondisi 1 induktor 1 mengalami proses charge karena terhubung dengan sumber tegangan secara langsung dan kondisi D1 mengalami revers bias. Sedangkan induktor 2 mengalami proses discharge karena tengangan sumber, induktor dan beban terhubung secara seri. Sehingga persamaan sebagai berikut :

$$
\begin{aligned}
& L \frac{d i_{L 1}}{d t}=V_{i n} \\
& L \frac{d i_{L 2}}{d t}=V_{i n}-V_{O} \\
& C \frac{d v_{o}}{d t}=i_{L 2}-\frac{V_{o}}{R}
\end{aligned}
$$


Kodisi 2: dimana $\mathrm{S} 1=$ BUKA dan $\mathrm{S} 2=$ TUTUP akan ditunjukan ilustrasi pada gambar 4.

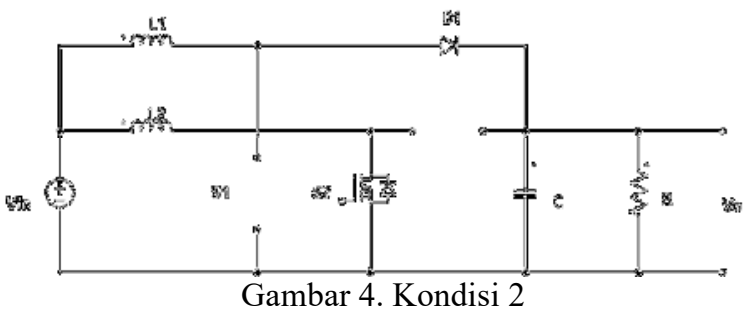

Pada kondisi 2 induktor 1 mengalami proses discharge karena tengangan sumber, induktor dan beban terhubung secara seri. Sedangkan induktor 2 mengalami proses charge karena terhubung dengan sumber tegangan secara langsung dan kondisi D2 mengalami revers bias. Sehingga persamaan sebagai berikut:

$L \frac{d i_{L 1}}{d t}=V_{i n}-V_{o}$

$L \frac{d i_{L 2}}{d t}=V_{\text {in }}$

$C \frac{d v_{O}}{d t}=i_{L 1}-\frac{V_{O}}{R}$

Kodisi 3: dimana $\mathrm{S} 1=$ TUTUP dan $\mathrm{S} 2=$ TUTUP akan ditunjukan ilustrasi pada gambar 5.

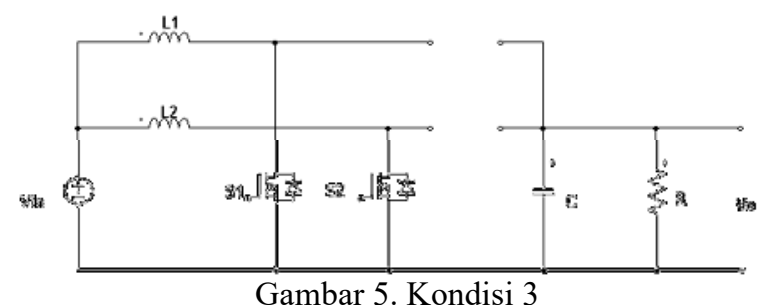

Pada kondisi 3 induktor 1 dan 2 mengalami proses charge karena terhubung dengan sumber tegangan secara langsung. Sehingga persamaan sebagai berikut:

$L \frac{d i_{L 1}}{d t}=V_{i n}$

$L \frac{d i_{L 2}}{d t}=V_{\text {in }}$
$C \frac{d v_{o}}{d t}=-\frac{V_{o}}{R}$

Kodisi 4: dimana $\mathrm{S} 1=$ BUKA dan $\mathrm{S} 2=$ BUKA akan ditunjukan ilustrasi pada gambar 6.

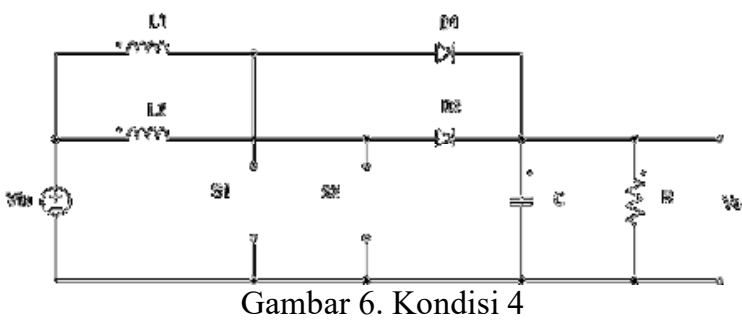

Pada kondisi 4 induktor 1 dan 2 mengalami proses discharge karena tengangan sumber, induktor dan beban terhubung secara seri. Sehingga persamaan sebagai berikut:

$L \frac{d i_{L 1}}{d t}=V_{\text {in }}-V_{o}$

$L \frac{d i_{L 2}}{d t}=V_{\text {in }}-V_{o}$

$C \frac{d v_{O}}{d t}=i_{L 1}+i_{L 2}-\frac{V_{O}}{R}$

\subsection{MPPT Bisection}

Daya listrik keluaran dari panel surya dapat dimaksimalkan dengan melakukan Maximum Power Point Tracker (MPPT). Metode MPPT yang akan digunakan yaitu menerapkan algoritma Bisection [1],[3],[4] untuk mendapatkan daya maksimum keluaran dari panel surya yang ditunjukkan seperti pada gambar 7.

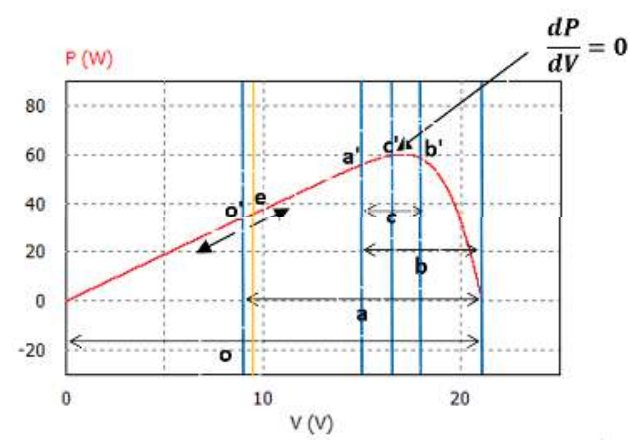

Gambar 7. Metode Bisection Untuk Mencari Daya Maksimum 


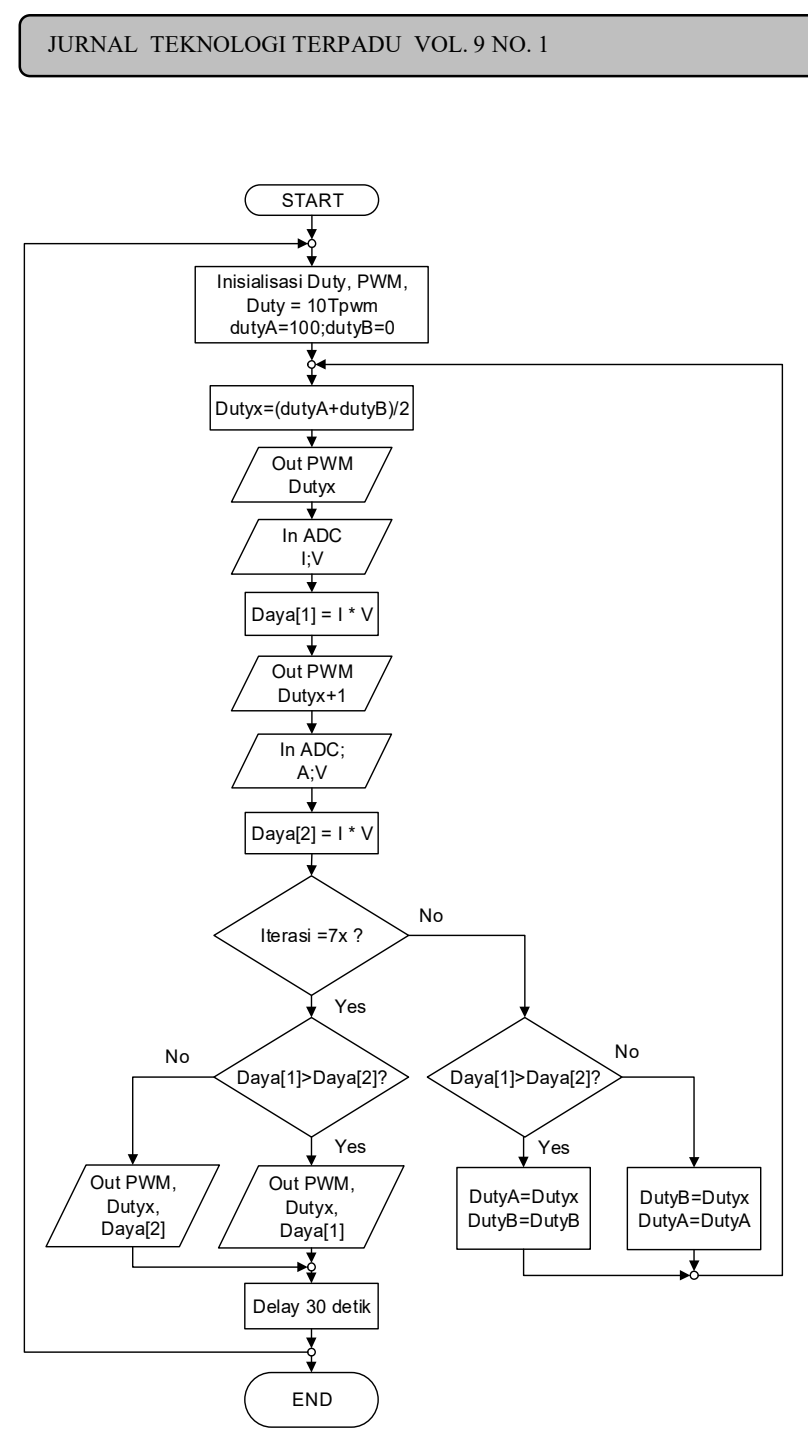

APRIL 2021 ISSN: $2338-66649$

perubahan turunnya nilai tegangan yang sebanding dengan turunnya perubahan daya maka daerah tersebut tidak terdapat nilai maksimum dari daya. Untuk $\mathrm{dP} / \mathrm{dV}=0$ maka sudah tidak terdapat perubahan nilai daya terhadap perubahan nilai tegangan sehingga di titik tersebut merupakan nilai maksimum dari daya yang dihasilkan sesuai dengan kurva karakteristik panel surya antara daya dengan tegangan. Untuk proses dari algoritma MPPT yang digunakan dapat dilihat pada gambar 8 .

\subsection{Baterai}

Baterai merupakan komponen elektrik yang sering digunakan untuk menyimpan energi listrik [5],[6],[8]. Ada berbagai tipe bateri diantaranya lead acid, lithium-ion, nickel-cadmium, dan nickel metal hydide. Salah satu jenis pemodelan baterai yang tepat digunakan dalam proses simulasi adalah pemodelan bateran dengan pemodelan rangkaian ekuivalen yang mengacu pada Sheperd Mode. Pemodelan baterai ini yaitu merangkai secara seri resistansi internal (hambatan dalam) dan terdiri juga dari tegangan terkontrol. Untuk rangkaian ekuivalen baterai ditunjukkan seperti gambar 9.

Gambar 8. Folowchart MPPT Metode Bisection

Untuk mencari titik maksimal dari daya yang dihasilkan oleh panel surya, pertama, daerah o dibagi menjadi dua bagian sehingga didapat titik o'. Pada titik o' akan dicari daerah mana yang memiliki titik maksimum dari daya dengan membandingkan nilai titik o' dengan titik sebelah kanan dari titik o' yaitu nilai titik e. Nilai antara titik o' dengan e merupakan nilai toleransi error untuk menentukan apakah daerah sebelah kanan atau kiri dari titik o' terdapat titik nilai maksimum dari daya. Apabila $\mathrm{dP} / \mathrm{dV}>0$ maka masih ada perubahan naiknya nilai tegangan yang sebanding dengan naiknya perubahan daya maka di daerah tersebut masih terdapat nilai maksimum dari daya. Sebaliknya $\mathrm{dP} / \mathrm{dV}<0$ maka ada

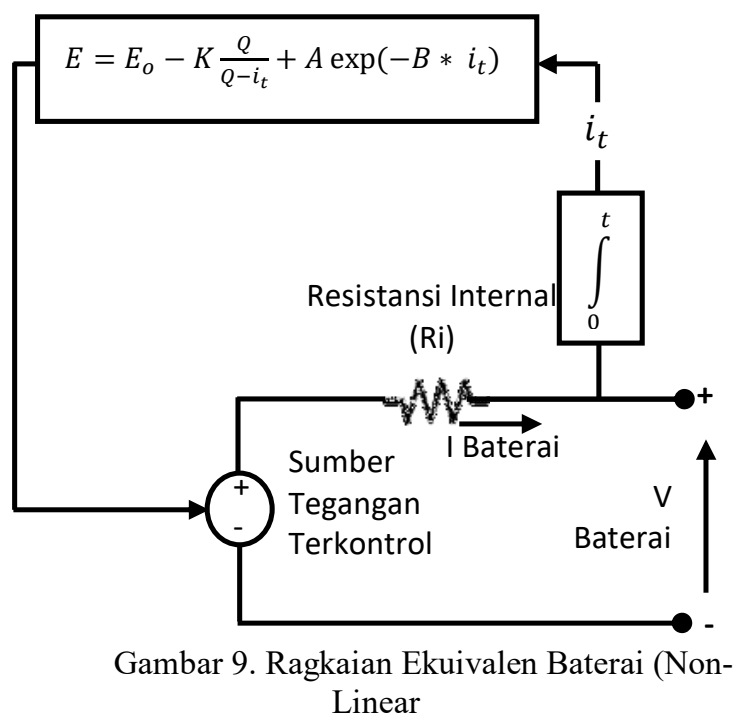

Sehingga untuk persamaan sumber tegangan terkontrol dapat ditunjukkan sebagai berikut: 
$E=E_{o}-K \frac{Q}{Q-\int i_{b} d t}+A \exp \left(-B \int i_{b} d t\right)(21)$

Dimana $E_{o}=$ tegangan konstan $(\mathrm{V}), K=$ konstanta polarisasi $\left(\mathrm{Ah}^{-1}\right), \mathrm{Q}=$ Kapasitas baterai masksimum (Ah), $i_{b}=$ kapasitas yang keluar (Ah), $\mathrm{A}=$ Tegangan eksponensial (V), $\mathrm{B}=$ Kapasistas eksponensial $\left((\mathrm{Ah})^{-1}\right)$.

Pada proses charge baterai dapat diketahui keadaan kapasitas baterai State of Charge dengan persamaan:

$S O C=100\left(1-\frac{\int_{0}^{t} i d t}{Q}\right)$

Dimana 100 adalah kondisi awal baterai (100 kondisi penuh dan 0 kondisi kosong), i arus baterai (A) dan $\mathrm{Q}$ merupakan kapasitas maksimum baterai (Ah).

\subsection{Desain Sistem}

Pada sistem yang dibangun merupakan proses memaksimalkan daya hasil keluaran dari panel surya dengan menggunakan MPPT Bisection. Hasil daya keluaran panel surya digunakan untuk melakukan charge pada baterai. Untuk desain dari sistem ditunjukkan pada gambar 10 .

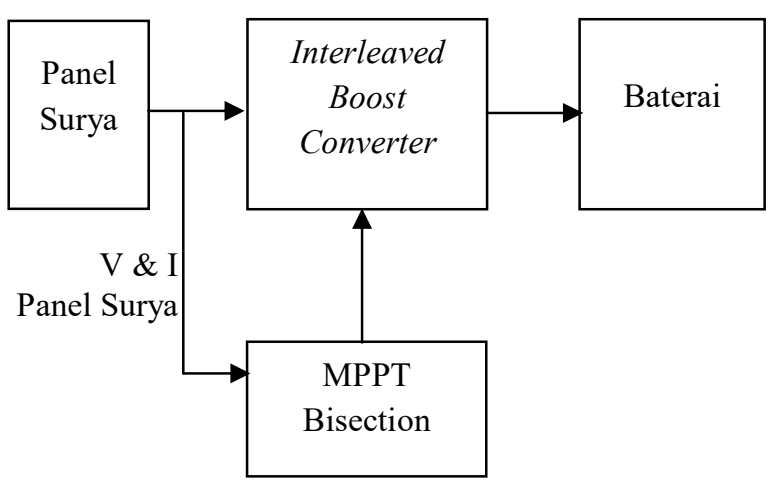

Gambar 10. Blok Diagram Sistem

Dari sistem yang ditunjukkan pada gambar 10 untuk memaksimalkan daya keluaran panel surya menggunakan MPPT Bisection yang mengimplementasikan Interleaved Boost Converter sebagai proses dalam menghasilan titik daya maksimum.
Panel surya yang digunakan 100 WP pada sistem ini memiliki spesifikasi pada tabel 1.

Tabel 1. Spesifikasi Panel Surya $100 \mathrm{WP}$

\begin{tabular}{ccc}
\hline No & Parameter & Nilai \\
\hline 1 & Imp & $5.69 \mathrm{~A}$ \\
\hline 2 & Vmp & $17.6 \mathrm{~V}$ \\
\hline 3 & Isc & $6.09 \mathrm{~A}$ \\
\hline 4 & Voc & $22.6 \mathrm{~V}$ \\
\hline 5 & Cell & 36 \\
\hline
\end{tabular}

Sesuai dengan sepsifikasi panel surya pada tabel 1 dapat ditunjukkan grafik karakteristik panel surya $100 \mathrm{WP}$ pada gambar 11 dan 12:

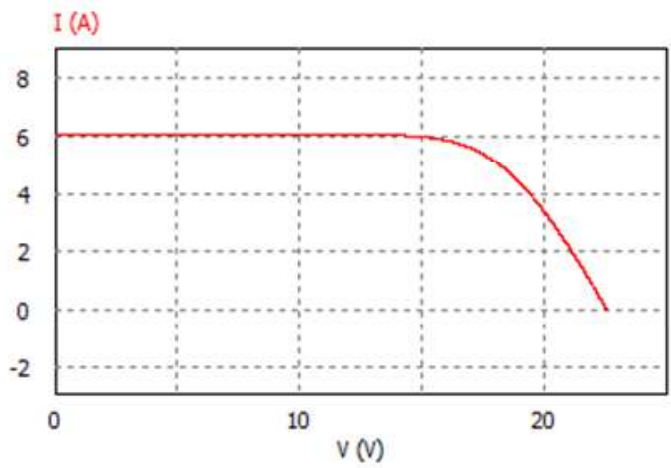

Gambar 11. Grafik Antara Tegangan dan Arus Panel Surya $100 \mathrm{WP}$

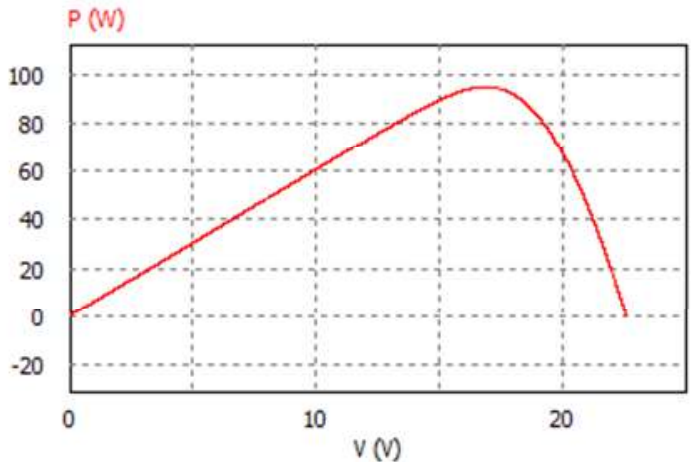

Gambar 12. Grafik Antara Tegangan dan Daya Panel Surya $100 \mathrm{WP}$

Untuk parmeter model panel surya dengan mengguakan simulasi PSIM ditunjukkan seperti pada gambar 13 .

Pada proses MPPT Bisection menggunakan Interleaved Boost Converter dengan 2 induktor dan 2 switching. Pada Interleaved Boost Converter menggunakan 
induktor sebesar $0,385 \mathrm{mH}$, kapasitor sebesar $0,128 \mathrm{mF}$ serta frekuensi untuk switching sebesar 35KHz. Algoritma MPPT Bisection dibangun dengan menggunakan $C$-Code yang disimulasikan dengan software PSIM.

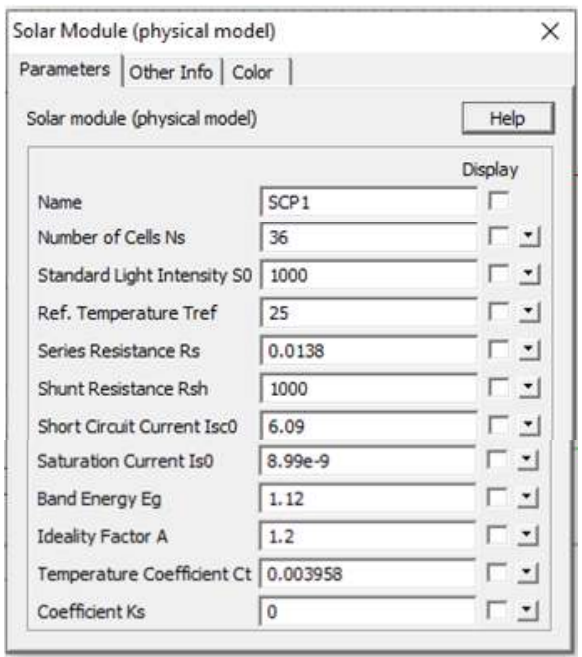

Gambar 13. Parameter Model Panel Surya 100 WP

Pada proses charge ditambakan diode sebagai proses pengaman charge. Pada sistem ini dilakukan proses charge pada baterai lithiuion Li32.4v18a, 32 Volt 18Ah Lithium Ion Battery yang biasa daplikasikan pada E-bike, mobility vehicles, cleaning equipment dan lainnya. Untuk mendapatkan parameter baterai dilakukan pada software Matlab sehingga dapat diketahui untuk parameter pemodelan ekuivalen dari baterai yaitu $\mathrm{Eo}=34.6995 \mathrm{~V}$, $\mathrm{a}=2.6872 \mathrm{~V}, \mathrm{Q}=18$ Ah, $\mathrm{B}=3.3923 \quad(\mathrm{Ah})^{-1}$, $\mathrm{K}=0.013319 \mathrm{Ah}^{-1}$ dan $\mathrm{Ri}=0.017778 \mathrm{ohm}$.

Untuk parameter baterai ditunjukkan seperti pada tabel 2 .

Tabel 2. Parameter Baterai

\begin{tabular}{ccc}
\hline No & Parameter & Nilai \\
\hline 1 & Battery Tipe & Li-ion \\
\hline 2 & Battery capacity & $18 \mathrm{Ah}$ \\
\hline 3 & Nominal Voltage & $32.4 \mathrm{~V}$ \\
\hline 4 & Max. Charge Voltage & $37.8 \mathrm{~V}$ \\
\hline 5 & Operating Temperature, & $0-55^{\circ} \mathrm{C}$ \\
& Charge & \\
\hline
\end{tabular}

\section{Hasil Penelitian}

Dari hasil sistem yang telah dilakukan dengan simulasi menggunakan software PSIM maka dapat diketahui proses dan hasil kinerja dari sistem. Hasil pengujian sistem yang dilakukan ditunjukkan dengan pengujian metode MPPT Bisection dan paramater proses charging pada baterai.

\subsection{Hasil Pengujian MPPT Bisection}

Simulasi MPPT Bisection telah berhasil dilakukan dengan software PSIM dan menunjukkan performa dari algoritma tersebut sehingga daya keluaran panel surya bisa mendekati daya maksimal panel surya. Proses pengujian dilakukan dengan memberikan nilai Standard Light Intensity (W/m2) yang berbeda pada panel surya dan mengukur hasil keluaran dari panel surya. Untuk data hasil keluaran daya panel surya ditunjukkan pada tabel 3 . Standard Light Intensity (W/m2) dalam hal ini irradiance yang digunakan pada simulasi panel surya ditentukan dengan mengacu pada Standard Test Conditions atau STC yaitu pada $1000 \mathrm{~W} / \mathrm{m} 2\left(25^{\circ} \mathrm{C}\right)$ dan dilakukan pengujian pada nilai $400(\mathrm{~W} / \mathrm{m} 2)$ dan $700(\mathrm{~W} / \mathrm{m} 2)$ secara sampling yang kedua nilai tersebut di bawah dari nilai STC untuk mengetahui MPPT Bisection berkerja.

Tabel 3. Hasil Keluaran Daya Panel Surya Berdasarkan Standard Light Intensity

\begin{tabular}{cccc}
\hline $\begin{array}{c}\text { Standard } \\
\text { Light } \\
\text { Intensity } \\
\text { (W/m2) }\end{array}$ & $\begin{array}{c}\text { Daya } \\
\text { Pansimum } \\
\text { (W) }\end{array}$ & $\begin{array}{c}\text { Daya } \\
\text { Keluaran } \\
\text { Panel Surya } \\
\text { (W) }\end{array}$ & $\begin{array}{c}\text { Effisiensi } \\
\text { Daya } \\
\text { Keluaran } \\
\text { Panel } \\
\text { Surya (\%) }\end{array}$ \\
\hline 400 & 39.64 & 39.58 & 99.84 \\
\hline 700 & 68.49 & 68.18 & 99.54 \\
\hline 1000 & 95.32 & 93.87 & 98.47 \\
\hline
\end{tabular}

Pegujian dari metode MPPT Bisection juga dilakukan dengan memberikan Standard Light Intensity (W/m2) yang berbeda secara langsung sehingga dapat mengetahui perubahan dari daya keluaran sehingga berjalannya algoritma MPPT Bisection dapat ditunjukkan dengan daya keluaran panel surya yang mengikuti besarnya daya maksimum pada panel surya. Untuk hasil pengujian ditunjukan dengan grafik perbandingan keluaran daya panel surya dengan daya 
maksimum panel surya seperti pada gambar 14.

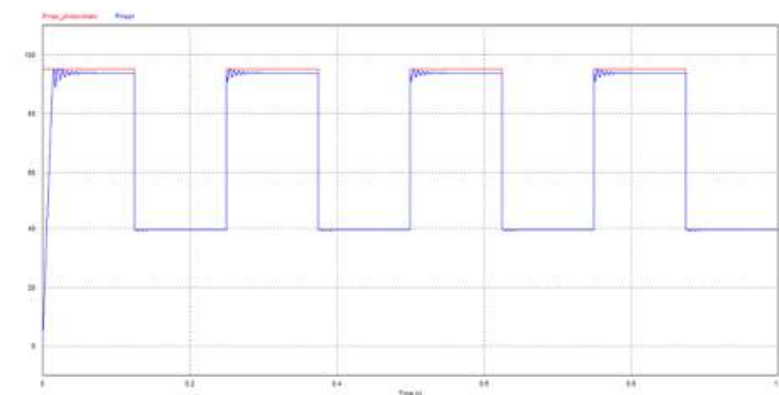

Gambar 14. Perbandingan Daya Maksimum dan Daya Keluaran Panel Surya Dengan MPPT Bisection

Pada gambar 14 terdapat 2 grafik yaitu grafik daya maksimum panel surya yang ditunjukan warna merah dan grafik daya keluaran panel surya yang ditunjukan warna biru. Terlihat daya keluaran dari panel surya selalu mengikuti/mendekati daya maksimum panel surya. Terlihat dari hasil pengujian pada saat Standard Light Intensity $400 \quad \mathrm{~W} / \mathrm{m} 2$ didapatkan hasil daya keluaran panel surya sebesar 39.58 Watt dari daya maksimum 39.64 Watt. Pada saat terjadi perubahan Standard Light Intensity menjadi $1000 \mathrm{~W} / \mathrm{m} 2$ didapatkan hasil daya keluaran panel surya sebesar 93.87 Watt dari daya maksimum 95.32 Watt.

\subsection{Perbandingan IBC dengan Boost}

Proses perbandingan pada sistem yang diusulkan yaitu Interleaved Boost Converter (IBC) dengan konvensional Boost digunakan untuk melihat keunggulan IBC dalam menurunkan ripple factor pada tegangan keluaran converter, dimana dari hasil perbandingan yang dilakukan dapat diketahui bahwa dengan menggunakan IBC ripple tegangan pada keluaran dari converter turun sebesar 26.4\%. Detail hasil simulasi perbandingan tersebut ditampilkan pada gambar 15 dan di uraikan pada table 4 .

Tabel 4. Perbandingan Boost dengan IBC

\begin{tabular}{lcc}
\hline Parameter yang diukur & Boost & IBC \\
\hline V mak (Volt) & 34.44 & 34.32 \\
\hline V min (Volt) & 34.10 & 34.23 \\
\hline V riple (Volt) & 0.34 & 0.09 \\
\hline
\end{tabular}

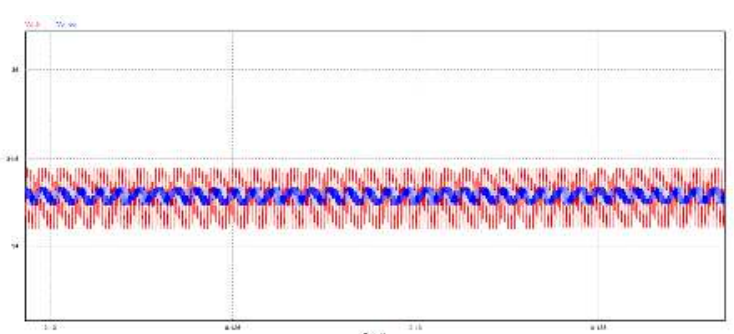

Gambar 15. Perbandingan Riple IBC dengan Boost

\subsection{Proses Charge Baterai}

Proses simulasi untuk charge baterai telah dilakukan. Keluaran daya listrik dari panel surya digunakan untuk charge baterai. Untuk grafik gelombang tegangan baterai yang merupakan keluaran dari IBC ditunjukkan seperti pada gambar 16 .

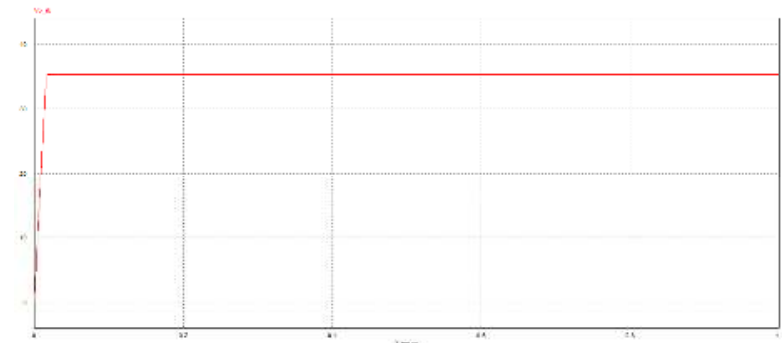

Gambar 16. Tegangan Charge Pada Baterai

Pada gambar 16 untuk tegangan charge baterai terdapat ripple tegangan dan apabila garfik diperbesar akan tampak pada gambar 17.

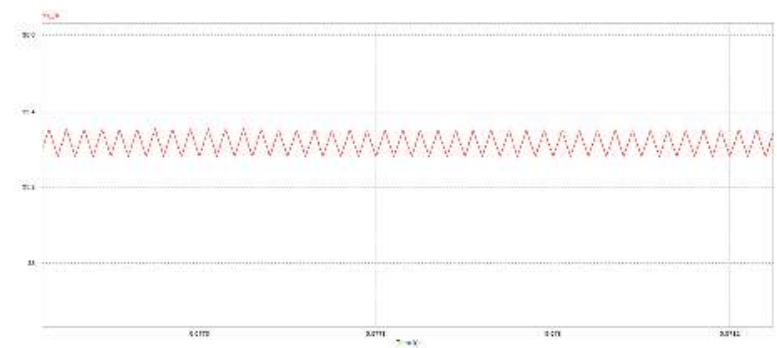

Gambar 17. Ripple Tegangan Charge Pada Baterai

Dari hasil simulasi pada kondisi Standard Light Intensity menjadi $1000 \mathrm{~W} / \mathrm{m} 2$ didapatkan data tegangan charge pada baterai seperti ditunjukkan pada tabel 5. Pada keluaran tegangan IBC dihasilkan ripel yang kecil sesuai dengan keluaran IBC yaitu menurunkan ripel tegangan. Pada IBC yang digunakan menggunakan 2 (dua) buah 
kompenen swiching yang memiliki proses switching berbeda phase. Untuk proses IBC terlihat dari kinejra 4 kondisi [2],[7],[9].

Tabel 5. Data Tegangan Charge Baterai

\begin{tabular}{ccc}
\hline No & Parameter & Nilai \\
\hline 1 & Maksimum Tegangan & $35.35 \mathrm{~V}$ \\
\hline 2 & Minimum Tegangan & $35.28 \mathrm{~V}$ \\
\hline 3 & $\begin{array}{c}\text { Tegangan Rata-rata } \\
\text { (Avg) }\end{array}$ & $35.31 \mathrm{~V}$ \\
\hline 4 & Rippel Tegangan & $0.19 \%$ \\
\hline
\end{tabular}

Pada gambar 18 menunjukkan kondisi State of Charge (SOC) mengalami kenaikan sehingga ini menunjukkan proses charging pada baterai berjalan.

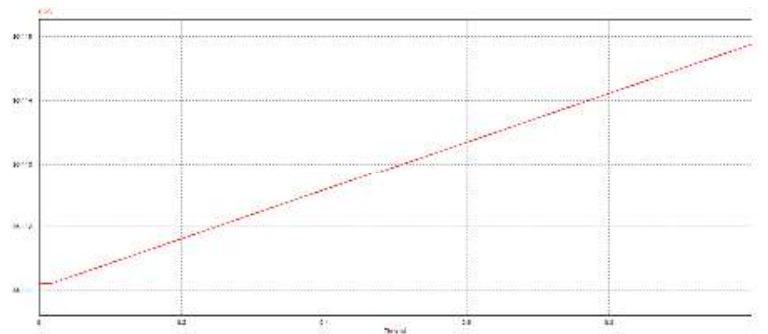

Gambar 18. SOC Pada Baterai

\section{Kesimpulan}

Dari hasil simulasi terlihat metode MPPT Bisection dapat berjalan dengan baik menggunakan IBC untuk mendapatkan daya maksimum dari panel surya. Pada saat ada dan tidak ada perubahan Standard Light Intensity (W/m2), metode MPPT Bisection berhasil mendapatkan daya keluaran panel surya mendekati daya maksimum yang dikeluarkan dari panel surya.

Pada proses charge baterai, tegangan yang digunakan memiliki ripple tegangan yang sangat kecil. Ini merupakan salah satu keunggulan dari IBC yaitu memiliki ripple tegangan keluaran yang sangat kecil. Proses charge sudah berjalan yang ditunjukkan dengan grafik State of Charge (SOC) yang nilainya terus meningkat.

\section{Saran}

Diperlukan adanya penambahan sistem pengaturan secara otomatis dan akurat pada tegangan charge baterai sehingga tegangan dapat terjaga sesuai kebutuhan dari baterai.

\section{Daftar Pustaka}

[1] Chun, S., "Analysis of Classical Root-Finding Methods Applied to Digital Maximum Power Point Tracking for Photovoltaic Energy Generation", Dissertation University of Texas at Austin, 2011.

[2] Indra Ferdiansyah, Era Purwanto, Indhana Sudiharto, Epyk Sunarno, Syechu Dwitya Nugraha, Ony Asrarul Qudsi, Lucky Pradigta Setiya Raharja, Mochamad Abdul Mughis, Ipensius Tua Simorangkir., "Application of Interleaved Bidirectional Converter on Pond Aerators with Electricity Sources from Solar Panels," 2019 International Conference on Electrical Engineering and Computer Science (ICECOS), Batam Island, Indonesia, pp. 107111, 2019.

[3] P. Wang, H. Zhu, W. Shen, F. H. Choo, P. C. Loh and K. K. Tan, "A novel approach of maximizing energy harvesting in photovoltaic systems based on bisection search theorem," 2010 Twenty-Fifth Annual IEEE Applied Power Electronics Conference and Exposition (APEC), Palm Springs, CA, pp. 2143-2148, 2010. H. S. Sahu, S. Kumar and S. K. Nayak, "Maximum Power Point Estimation of a PV Array by Using Improve Bisection Method," 2018 IEEE Transportation Electrification Conference and Expo, Asia-Pacific (ITEC Asia-Pacific), Bangkok, pp. 1-5, 2018.

[4] H. S. Sahu, S. Kumar and S. K. Nayak, "Maximum Power Point Estimation of a PV Array by Using Improve Bisection Method," 2018 IEEE Transportation Electrification Conference and Expo, Asia-Pacific (ITEC Asia-Pacific), Bangkok, pp. 1-5, 2018.

[5] Lucky Pradigta Setiya Raharja, Rachma Prilian Eviningsih, Indra Ferdiansyah, Diah Septi Yanaratri, "Perancangan Dan Implementasi DC-DC Bidirectional Converter Dengan Sumber Energi Listrik Dari Panel Surya Dan Baterai Untuk Pemenuhan Kebutuhan Daya Listrik Beban", JURNAL TEKNOLOGI TERPADU VOL. 7 NO. 2, pp 111-118., 2019.

[6] S. Padhee, U. C. Pati and K. Mahapatra, "Design of photovoltaic MPPT based charger for lead-acid batteries," 2016 IEEE International Conference on Emerging Technologies and Innovative Business Practices for the Transformation of Societies (EmergiTech), Balaclava, 2016, pp. 351-356, 2016. 
[7] K. Latha Shenoy, C.Gurudas Nayak, Rajashekar P Mandi, "Design and Implementation of Interleaved Boost Converter", International Journal of Engineering and Technology (IJET), Vol 9 No 3S, pp 496 - 502, July 2017.

[8] R. P. Eviningsih, R. I. Putri, M. Pujiantara, A. Priyadi and M. H. Purnomo, "Controlled bidirectional converter using PID for charging battery in the stand-alone wind turbine system with Modified P\&O to obtain MPPT," International Conference on Green Energy and Applications (ICGEA), Singapore, 2017, pp. 69-73, 2017.

[9] Yin Yin Phyo, Tun Lin Naing, "Modeling and Simulation of Two-Phase Interleaved Boost Converter Using Open-Source Software Scilab/Xcos", World Academy of Science, Engineering and Technology International Journal of Electrical and Computer Engineering, Vol: 12, No: 10, pp $781-786$, 2018. 